Pacific Journal of Mathematic 


\section{A NOTE ON THE CONTINUITY OF BEST POLYNOMIAL APPROXIMATIONS}

\section{S. J. POREDA}

An example is given to show that while best uniform polynomial approximation in the complex plane is continuous, it is not in geneal uniformly continuous.

For a continuous complex valued function $f$ defined on $E$, a compact set in the plane and $n \in\{0,1,2, \cdots\}$, let $p_{n}(f, E)$ denote the polynomial of degree $n$ of best uniform approximation to $f$ on $E$ and let $\|f\|_{E}$ denote the uniform norm of $f$ on $E$. In [2] it was shown that for any such $f$ and $E$ there exists for each $n$ and each $\beta, 0<$ $\beta<1 / 2$, a constant $M(n, \beta)>0$ such that

$$
\left\|p_{n}(f, E)-q_{n}\right\|_{E} \leqq M(n, \beta)\left[\left\|f-q_{n}\right\|_{E}-\left\|f-p_{n}(f, E)\right\|_{E}\right]^{\beta},
$$

where $q_{n}$ is any polynomial of degree $n$. If we in fact let $M(n, \beta)$ denote the least such constant then we ask if the sequence $\{M(n, \beta)\}_{n=0}^{\infty}$ is bounded. The purpose of this note is to show that in general it is not.

Let $f(z)=1 / z$ and $E=U=\{|z|=1\}$. Then $p_{n}(f, U) \equiv 0$ for $n=0,1,2, \cdots$. Now for each $k=1,2, \cdots$ and each $\beta, 0<\beta<1 / 2$, let $\Omega_{k, \beta}$ denote a simply connected Jordan region containing the origin such that

1. $\Omega_{k, \beta} \subset\left\{|\boldsymbol{z}|<k^{\beta}\right\}$

2. $k^{\beta} \in \bar{\Omega}_{k, \beta}$

3. $\Omega_{k, \beta} \cap\{|z|>k(\beta-1) / \beta\} \cap\{\operatorname{Re} z \leqq 0\}=\Phi$.

The region $\Omega_{k, \beta}$ can in fact be chosen to be a displaced ellipse. Futhermore, there exists a conformal map $g_{k, \beta}$ of the unit disc $\{|z|<1\}$ onto $\Omega_{k, \beta}$ such that $g_{k, \beta}(0)=0$. Furthermore $g_{k, \beta}$ will be continuous in $\{|z| \leqq 1\}$ and map $U$ onto the boundary of $\Omega_{k, \beta}$. As a consequence of these definitions we have that

$$
\left\|1-g_{k, \beta}(z) / k\right\|_{U} \leqq 1+(1 / k)^{1 / \beta}
$$

and

$$
\left\|g_{k, \beta}(z) / k\right\|_{U}=k^{\beta} / k
$$

Now there exists $[1$, p. 98$]$ a polynomial $p$ such that

$$
\left\|g_{k, \beta}(z) / z-p(z)\right\|_{U}<k^{(\beta-1) / \beta} .
$$

Thus 


$$
\|1 / z-p(z) / k\|_{U} \leqq 1+2(1 / k)^{1 / \beta}
$$

and

$$
\|p(z) / k\|_{U} \geqq \frac{k^{\beta}-k^{(\beta-1) / \beta}}{k}=\frac{k^{\beta}-k^{(\beta-1) / \beta}}{2^{\beta}}\left(\frac{2^{\beta}}{k}\right) .
$$

Consequently, we see that for this particular choice of $f$ and $E$, and for each $0<\beta<1 / 2$,

$$
\lim _{n \rightarrow \infty} M(n, \beta) \geqq \lim _{k \rightarrow \infty}\left(\frac{k^{\beta}-k^{(\beta-1) / \beta}}{2^{\beta}}\right)=\infty .
$$

\section{REFERENCES}

1. Gunter Meinardus, Approximation of Functions: Theory and Numerical Methods, Springer-Verlag, (1967).

2. S. J. Poreda, On the continuity of best polynomial approximations, Proc. Amer. Math. Soc., November, 1972.

Received September 28, 1972.

Clark University 


\section{PACIFIC JOURNAL OF MATHEMATICS}

\section{EDITORS}

RICHARD ARENS (Managing Editor)

University of California

Los Angeles, California 90024

R. A. BeAumont

University of Washington

Seattle, Washington 98105
J. DugundJI*

Department of Mathematics

University of Southern California

Los Angeles, California 90007

D. Gilbarg and J. Milgram

Stanford University

Stanford, California 94305

\section{ASSOCIATE EDITORS}

E. F. BECKENBACH

B. H. NEUMANN

F. WOLF

K. YoSHIDA

\section{SUPPORTING INSTITUTIONS}

UNIVERSITY OF BRITISH COLUMBIA
CALIFORNIA INSTITUTE OF TECHNOLOGY
UNIVERSITY OF CALIFORNIA
MONTANA STATE UNIVERSITY
UNIVERSITY OF NEVADA
NEW MEXICO STATE UNIVERSITY
OREGON STATE UNIVERSITY
UNIVERSITY OF OREGON
OSAKA UNIVERSITY

UNIVERSITY OF BRITISH COLUMBIA CALIFORNIA INSTITUTE OF TECHNOLOGY UNIVERSITY OF CALIFORNIA MONTANA STATE UNIVERSITY NEW MEXICO STATE UNIVERSITY UNIVERSITY OF OREGON OSAKA UNIVERSITY
UNIVERSITY OF SOUTHERN CALIFORNIA STANFORD UNIVERSITY UNIVERSITY OF TOKYO UNIVERSITY OF UTAH WASHINGTON STATE UNIVERSITY UNIVERSITY OF WASHINGTON AMERICAN MATHEMATICAL SOCIETY NAVAL WEAPONS CENTER

* C. R. DePrima California Institute of Technology, Pasadena, CA 91109, will replace J. Dugundji until August 1974. 


\section{Pacific Journal of Mathematics}

\section{Vol. 51, No. $1 \quad$ November, 1974}

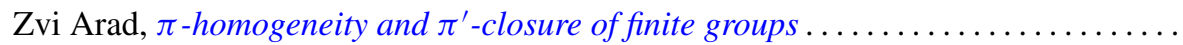

Ivan Baggs, A connected Hausdorff space which is not contained in a maximal

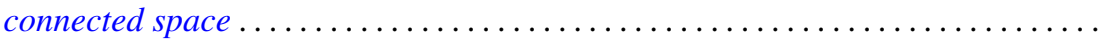

Eric Bedford, The Dirichlet problem for some overdetermined systems on the unit ball in $C^{n}$

R. H. Bing, Woodrow Wilson Bledsoe and R. Daniel Mauldin, Sets generated by

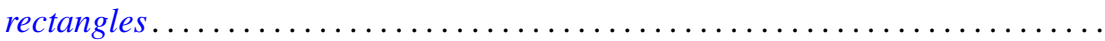

Carlo Cecchini and Alessandro Figà-Talamanca, Projections of uniqueness for

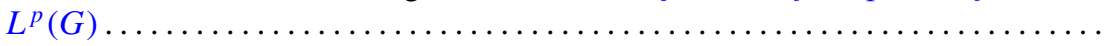

Gokulananda Das and Ram N. Mohapatra, The non absolute Nörlund summability of Fourier series .

Frank Rimi DeMeyer, On separable polynomials over a commutative ring ........ Richard Detmer, Sets which are tame in arcs in $E^{3} \ldots \ldots \ldots \ldots \ldots \ldots \ldots \ldots$

William Erb Dietrich, Ideals in convolution algebras on Abelian groups ..........

Bryce L. Elkins, A Galois theory for linear topological rings .................

William Alan Feldman, A characterization of the topology of compact convergence on $C(X)$.

Hillel Halkin Gershenson, A problem in compact Lie groups and framed cobordism

Samuel R. Gordon, Associators in simple algebras.

Marvin J. Greenberg, Strictly local solutions of Diophantine equations

Jon Craig Helton, Product integrals and inverses in normed rings . . . . . . . . . . . .

Domingo Antonio Herrero, Inner functions under uniform topology . . .

Jerry Alan Johnson, Lipschitz spaces .

Marvin Stanford Keener, Oscillatory solutions and multi-point boundary value

functions for certain nth-order linear ordinary differential equations.

John Cronan Kieffer, A simple proof of the Moy-Perez generalization of the

Shannon-McMillan theorem .......................

Joong Ho Kim, Power invariant rings

Gangaram S. Ladde and V. Lakshmikantham, On flow-invariant sets .

Roger T. Lewis, Oscillation and nonoscillation criteria for some self-adjoint even

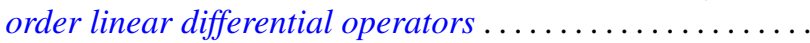

Jürg Thomas Marti, On the existence of support points of solid convex sets ..

John Rowlay Martin, Determining knot types from diagrams of knots . .

James Jerome Metzger, Local ideals in a topological algebra of entire functions

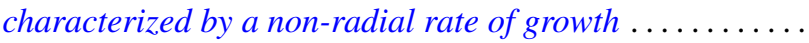

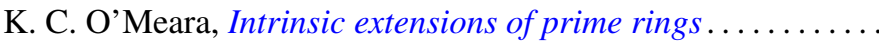

Stanley Poreda, A note on the continuity of best polynomial approximations ..

Robert John Sacker, Asymptotic approach to periodic orbits and local prolongations

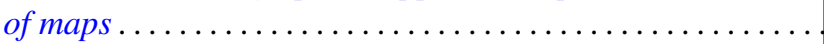

Eric Peter Smith, The Garabedian function of an arbitrary compact set . .

Arne Stray, Pointwise bounded approximation by functions satisfying a side condition

John St. Clair Werth, Jr., Maximal pure subgroups of torsion complete abelian

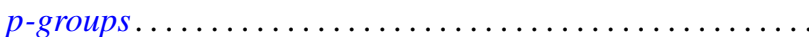

